\title{
The influence of osmotic shocks on the growth rate and chlorophyll- $a$ content of planktonic algae species
}

\author{
Teresa Cristina S. SIGAUD-KUTNER \& Elizabeth AIDAR
}

Instituto Oceanográfico da Universidade de São Paulo

(Caixa Postal 66149, 05389-970 São Paulo, SP, Brasil)

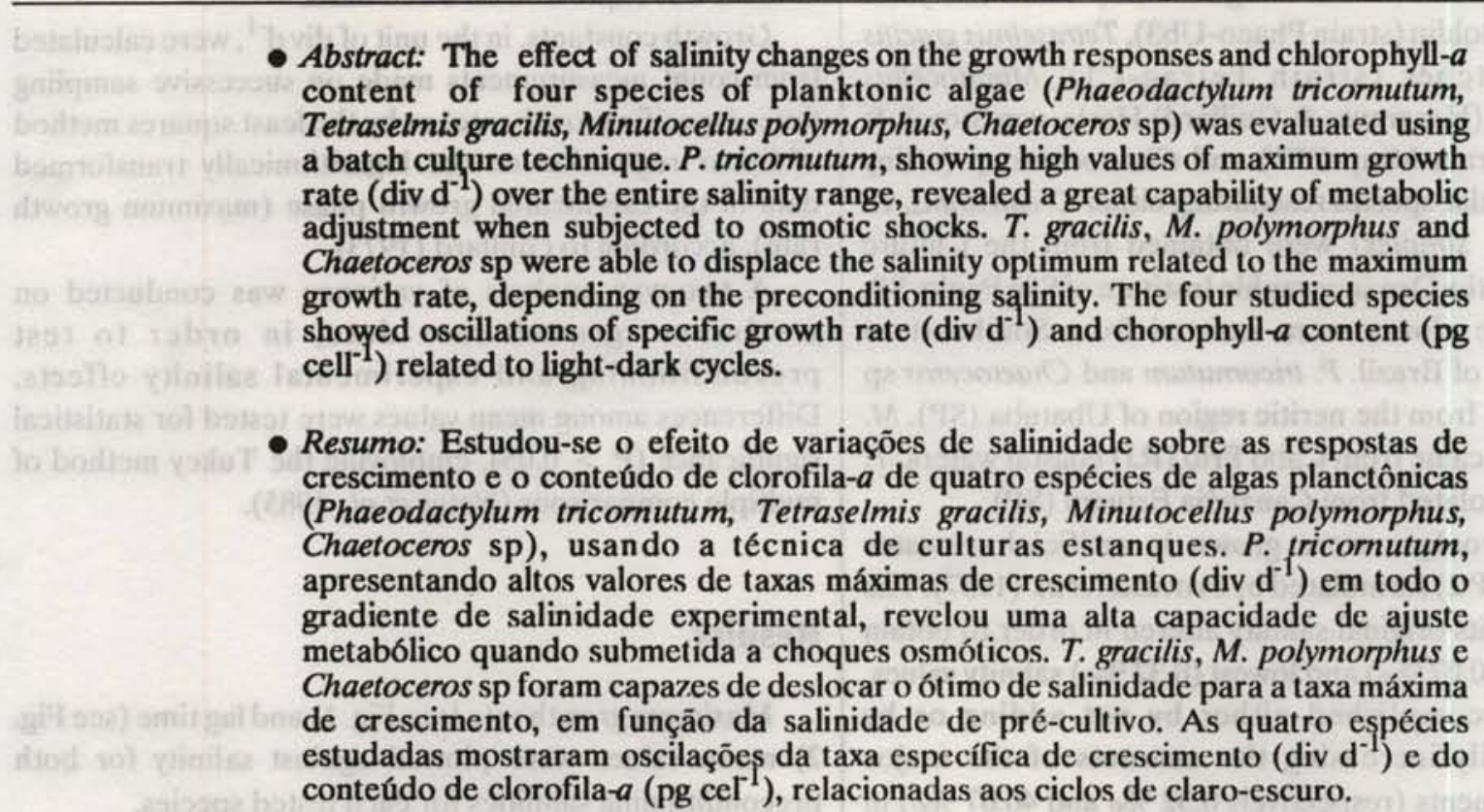

- Descriptors: Algal assays, Salinity changes, Phaeodactylum tricomutum, Tetraselmis gracilis, Minutocellus polymorphus, Chaetoceros sp.

- Descritores: Bioensaios unialgais, Variaçôes de salinidade, Phaeodactylum tricomutum, Tetraselmis gracilis, Minutocellus polymorphus, Chaetoceros $\mathrm{sp}$.

\section{Introduction}

In the marine environment, particularly in brackish-water ponds, salt marshes, estuaries and inshore areas, where there are great fluctuations of salt concentration, salinity is considered one of the most important ecological variables, affecting the metabolic responses and the distribution patterns of planktonic algae (Gessner \& Schramm, 1971; Maeda et al., 1973; Mahoney \& McLaughlin, 1979; Smayda, 1980).

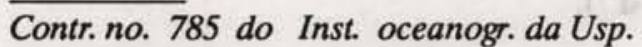

Phytoplankton, as a group, exhibits an impressive wide tolerance to salt concentration. The ranges of salinity tolerance have been established for a number of phytoplankton species (Qasim et al., 1972; Paasche, 1975; Fabregas et al., 1984, 1985, 1987; Tsuruta et al., 1985), with estuarine species being the most euryhaline and oceanic species the most stenohaline; coastal species are intermediate in their tolerance (Brand, 1984). However, studies concerning the mechanisms of microalgae adaptation to water stress, especially growth adaptive responses are fragmentary (Hellebust, 1976; Liu \& Hellebust, 1976; Shimura et al., 1979; Brown, 1982a,b). 
Batch cultures are helpful tools for understanding the environmental factor effects on metabolic responses of phytoplankton. Regarding this subject, optimum conditions of temperature and salinity for culturing $P$. tricomutum, T. gracilis, M. polymorphus and Chaetoceros sp have already been established (Sigaud, 1990). In the present investigation, we attempted to explore the impact of salinity changes on growth and chlorophyll- $a$ content of these four microalgae species.

\section{Materials and methods}

The experimental organisms, Phaeodactylum tricomutum Bohlin (strain Phaeo-Ub3), Tetraselmis gracilis (Kylin) Butcher (strain Tetrag-C1), Minutocellus polymorphus (Hargraves \& Guillard) Hasle, von Stosch \& Syvertsen (strain Minp-CF1) and Chaetoceros sp (a tiny small unicellular species resembling either $C$. calcitrans, $C$. gracilis or $C$. simplex) were obtained from the Culture Collection of the Oceanographic Institute of São Paulo, SP, Brazil. These clones were isolated from Southeastern coastal areas of Brazil. P. tricormutum and Chaetoceros sp were isolated from the neritic region of Ubatuba (SP). $M$. polymorphus came from Cabo Frio (RJ) coastal waters. $T$. gracilis was isolated from Cananéia Estuary (SP).

The microalgae were grown in artificial seawater medium (ASP 2) formulated by Provasoli et al. (1957). The medium had its original salinity altered in order to obtain the highest $(40.07 \%$ ) and lowest $(0.32 \%$ ) salinity values. This was accomplished either by not adding or by proportionally increasing the amounts of the major seawater elements (respectively $0.32 \% 0$ and $40.07 \% 0$ ) in the medium. Intermediate salinity media $(3.57,9.02,14.42$, $19.77,25.18,30.14$ and $35.14 \%$ ) were prepared by differential mixture of both extreme salinity media. Salinity was measured with a refractometer (Goldberg T/C) and checked by conductivity and chlorinity determinations.

Cultures were maintained with a reduced number of bacteria in 2 -1 borosilicate flasks at two salinities $(35.14 \%$ ) and the lowest experimental growth salinity, under the optimum previously established temperature for each organism: $21^{\circ} \mathrm{C}$ for $P$. tricomutum and $T$. gracilis; $26^{\circ} \mathrm{C}$ for M. polymorphus and Chaetoceros sp (Sigaud, 1990). These flasks were placed under temperature and light controlled incubators. The selected photosynthetically active radiation $\left(125 \mu \mathrm{E} \mathrm{s}^{-1} \mathrm{~m}^{-2}\right.$ ), provided by fluorescent lamps (TLD 15W/54), was measured with a Lambda Instruments LI-190S quantum sensor connected to a Lambda Instruments LI-185S quantum meter (Lambda Instruments Corp., Lincoln, NE). A 12:12 light-dark cycle was chosen.

After being precultured for five days under the above described conditions, algal cells were harvested by centrifugation, washed once or twice with fresh medium, and inoculated in triplicates into $200 \mathrm{ml}$ new media of salinities from $0.32 \%$ to $40.07 \%$ to yield an initial cell concentration of about $10^{5}$ cells ml $\mathrm{ml}^{-1}$.

Growth of microalgae in each Erlenmeyer flask was followed by counting the cells with hemacytometers, at approximately every 12 hours, for four days. Simultaneously, chlorophyll- $a$ measurements were performed.

For chlorophyll determinations culture aliquots from each treatment were put together and filtered onto a GF/F Whatman filter and analysed by the spectrophotometric technique Strickland \& Parsons (1968) . Chlorophyll- $a$ content was expressed on a cell basis.

Growth constants, in the unit of div $\mathrm{d}^{-1}$, were calculated from count measurements made on successive sampling times (specific growth rate) or by the least squares method of linear regression on the logarithmically transformed data in the exponential growth phase (maximum growth rate), according to Guillard (1973).

A two-way analysis of variance was conducted on maximum growth rate data, in order to test preconditioning and experimental salinity effects. Differences among mean values were tested for statistical significance ( $\mathrm{P}>0.05$ ), employing the Tukey method of multiple comparisons (Neter et al., 1985).

\section{Results}

Maximum growth rate (see Fig. 1) and lag time (see Fig. 2) mean values were plotted against salinity for both preconditioning salinities for each tested species.

Statistical treatment applied to maximum growth rate data of $P$. tricomutum revealed that the preconditioning salinity of $35.1 \%$ was the most favourable for the attainment of maximum values. For the lower preculturing salinity $(3.6 \%)$, data did not differ significantly between 3.6-35.1\%o (about $1.0 \mathrm{div} \mathrm{d}^{-1}$ ). For the $35.1 \%$ preconditioning salinity, this range was even wider, between 3.6-40.1\%o (about $1.4 \mathrm{div} \mathrm{d}^{-1}$ ); at $0.3 \%$ the highest value was obtained $\left(1.72 \operatorname{div~}^{-1}\right) . T$. gracilis presented maximum values at salinities between 9.0-40.1\%o for 3.6\%o preconditioning salinity (about 1.1 $\operatorname{div} \mathrm{d}^{-1}$ ) and between 19.8-40.1\%o for $35.1 \%$ preconditioning salinity (about $1.5 \mathrm{div}^{-1}$ ). $M$. polymorphus showed the highest values at 14.4-30.1\%o for 14.4\%o preconditioning salinity (about $2.1 \mathrm{div} \mathrm{d}^{-1}$ ) and between $14.4-40.1 \%$ for $35.1 \% 0$ preconditioning salinity (about $1.9 \mathrm{div} \mathrm{d}^{-1}$ ). Chaetoceros sp exhibited the highest values at narrower salinity ranges: 14.4-19.8\%o for $9.0 \%$ preconditioning salinity (about $3.9 \mathrm{div} \mathrm{d}^{-1}$ ) and $30.1-35.1 \%$ for $35.1 \%$ preconditioning salinity (about $3.3 \operatorname{div~d}^{-1}$ ). 

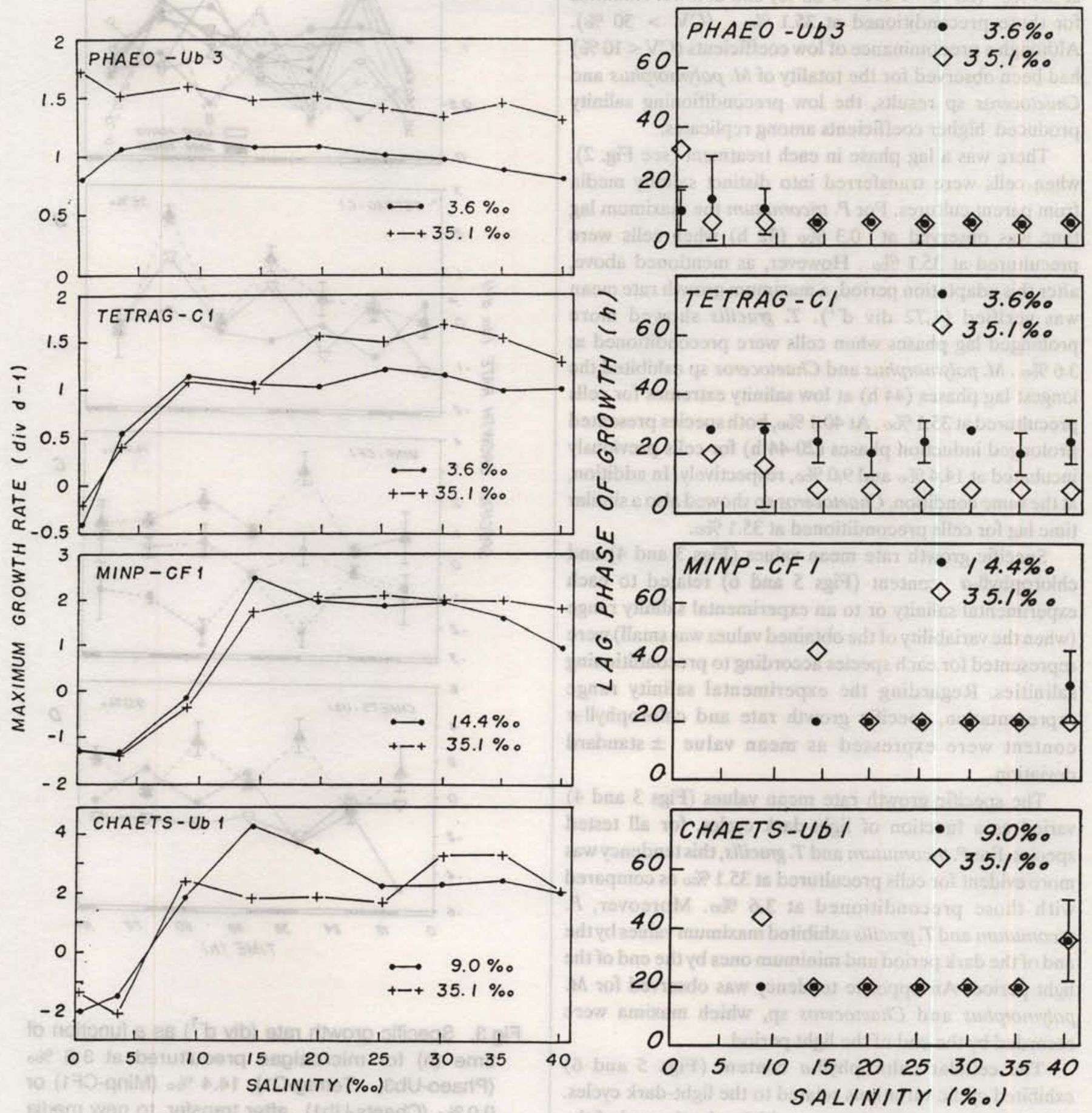

Fig. 1. Maximum growth rate $\left(\mathrm{div}^{-1}\right)$ for microalgae precultured at $3.6 \%$ (Phaeo-Ub3, Tetrag-C1), $14.4 \%$ (Minp-CF1) or $9.0 \%$ (Chaets-Ub1) and $35.1 \%$, after transfer to new media of different salinities.
Fig. 2. Lag phase of growth (h) and respective standard deviations for microalgae precultured at $3.6 \%$ (Phaeo-Ub3, Tetrag-C1), $14.4 \%$ (Minp-CF1) or $9.0 \%$ (Chaets-Ub1) and $35.1 \%$, after transfer to new media of different salinities. The lack of standard deviation (SD) bars represents a SD value equal to zero. 
The coefficients of variation among replicates were low $(\mathrm{CV}<10 \%)$ for almost the totality of $P$. tricomutum maximum growth rates. $T$. gracilis replicates showed the greatest variability at higher salinities for cells precultured at $3.6 \%$ o $(20 \%<\mathrm{CV}<30 \%)$ and at lower salinities for those preconditioned at $35.1 \%$ (CV > $30 \%)$. Although a predominance of low coefficients $(\mathrm{CV}<10 \%)$ had been observed for the totality of $M$. polymorphus and Chaetoceros sp results, the low preconditioning salinity produced higher coefficients among replicates.

There was a lag phase in each treatment (see Fig. 2), when cells were transferred into distinct salinity media from parent cultures. For $P$. tricornutum the maximum lag time was observed at $0.3 \%$ ( $32 \mathrm{~h})$ when cells were precultured at $35.1 \% 0$. However, as mentioned above, after this adaptation period, a maximum growth rate mean was verified $\left(1.72 \mathrm{div}^{-1}\right) . T$. gracilis showed more prolonged lag phases when cells were preconditioned at $3.6 \%$. M. polymorphus and Chaetoceros sp exhibited the longest lag phases ( $44 \mathrm{~h})$ at low salinity extremes for cells precultured at $35.1 \%$. At $40.1 \%$, both species presented prolonged induction phases $(20-44 \mathrm{~h})$ for cells previously incubated at $14.4 \%$ and $9.0 \%$, respectively. In addition, at the same condition, Chaetoceros sp showed also a similar time lag for cells preconditioned at $35.1 \%$.

Specific growth rate mean values (Figs 3 and 4 ) and chlorophyll-a content (Figs 5 and 6) related to each experimental salinity or to an experimental salinity range (when the variability of the obtained values was small) were represented for each species according to preconditioning salinities. Regarding the experimental salinity range representation, specific growth rate and chlorophyll- $a$ content were expressed as mean value \pm standard deviation.

The specific growth rate mean values (Figs 3 and 4) varied as a function of light-dark cycles, for all tested species. For P. tricomutum and T. gracilis, this tendency was more evident for cells precultured at $35.1 \%$ as compared with those preconditioned at $3.6 \%$. Moreover, $P$. tricomutum and $T$. gracilis exhibited maximum values by the end of the dark period and minimum ones by the end of the light period. An opposite tendency was observed for $M$. polymorphus and Chaetoceros $\mathrm{sp}$, which maxima were recorded by the end of the light period.

The cellular chlorophyll- $a$ content (Figs 5 and 6) exhibited cyclic variations related to the light-dark cycles. Chlorophyll concentrations were higher by the end of the light exposition period and lower by the end of the dark period. This pattern seemed to change when cells were transferred to the low salinity extremes, where there was no growth. Under these conditions, $M$. polymorphus and Chaetoceros sp showed great increases in cellular chlorophyll- $a$ content, mainly for cells previously incubated at lower salinities (Fig. 5).

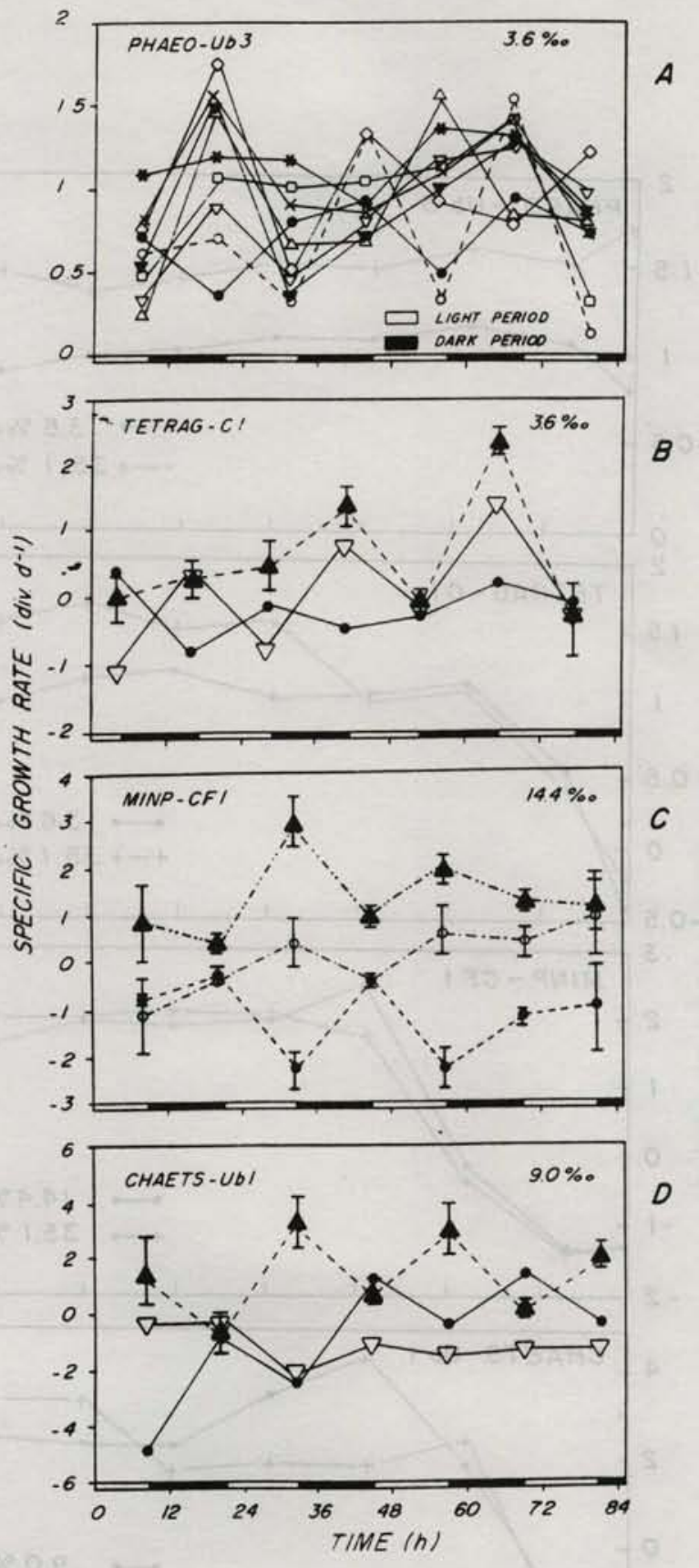

Fig.3. Specific growth rate (div $\left.\mathrm{d}^{-1}\right)$ as a function of time (h) for microalgae precultured at $3.6 \%$ (Phaeo-Ub3, Tetrag-C1), $14.4 \%$ \% (Minp-CF1) or $9.0 \%$ (Chaets-Ub1), after transfer to new media of different salinities. Experimental salinities: A) - $0.3 \%$; $\nabla$ _ $\nabla 3.6 \%$; * ${ }^{*} 9.0 \%$; D_ $14.4 \%$; X_X 19.8\%o; $\diamond_{-} \diamond 25.2 \%$; $\Delta_{-} \Delta 30.1 \% \circ ; \nabla_{-} \nabla$ $35.1 \% \circ ;$ O_O $40.1 \%$. B) $\bullet 0.3 \%$; $\nabla \_\nabla 3.6 \%$; $\Delta \Delta \bar{S}(9.0-40.1 \% \circ) \pm \overline{S D}$. C) $-\bar{S}(0.3-$ $3 . \overline{6} \%$ o) \pm SD; $O_{\text {_. }} \mathrm{O} \overline{\mathrm{S}}(9.0 \%$; $40.1 \% \circ) \pm$ SD; $\Delta_{-} . . \Delta \bar{S}(14.4-35.1 \% \circ) \pm S D$. D) •_ $0.3 \%$; $\nabla \ldots \nabla 3.6 \% ; \Delta \_\Delta \bar{S}(9.0-40,1 \% \circ) \pm \overline{S D}$. 

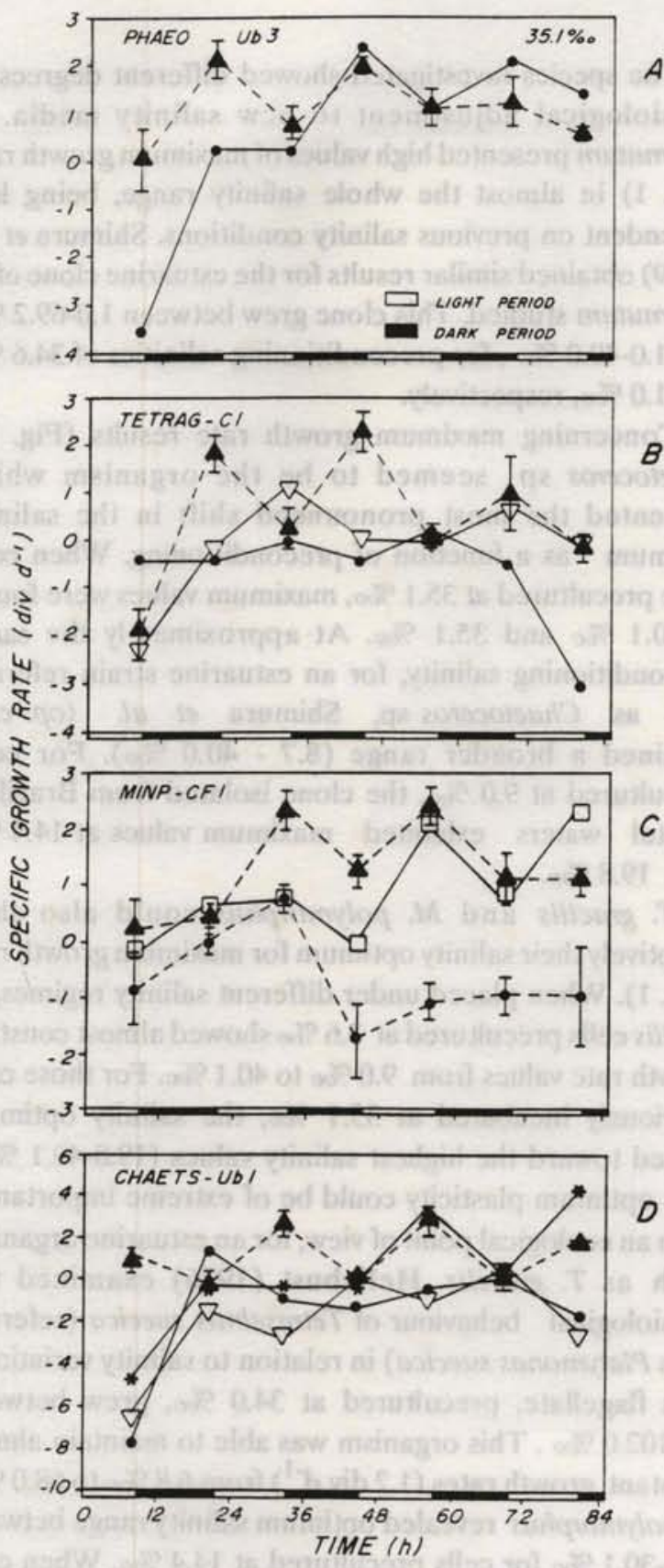

Fig. 4. Specific growth rate $\left(\operatorname{div~} \mathrm{d}^{-1}\right)$ as a function of time (h) for microalgae precultured at $35.1 \%$, after transfer to new media of different salinities. Experimental salinities: A) $\bullet-0.3 \% \circ ; \Delta-\overline{\mathrm{S}}$ $(3.6-40.1 \% \circ) \pm$ SD. B) $\bullet 0.3 \%$; $\nabla \nabla 3.6 \%$; $\Delta \overline{\mathrm{S}}(9.0-40.1 \% \circ) \pm \mathrm{SD}$. C) $(0.3-9.0 \%$ o $) \pm S D ; 0 \_14.4 \%$; $\Delta$ _ $\bar{S}(\overline{19} .8$ $40.1 \% \circ) \pm \mathrm{SD}$. D) • $0.3 \%$; $\nabla \nabla 3.6 \%$; * * $9.0 \% \circ ; \_\_\bar{S}(14.4-\overline{4} 0.1 \% \circ) \pm S \bar{D}$.

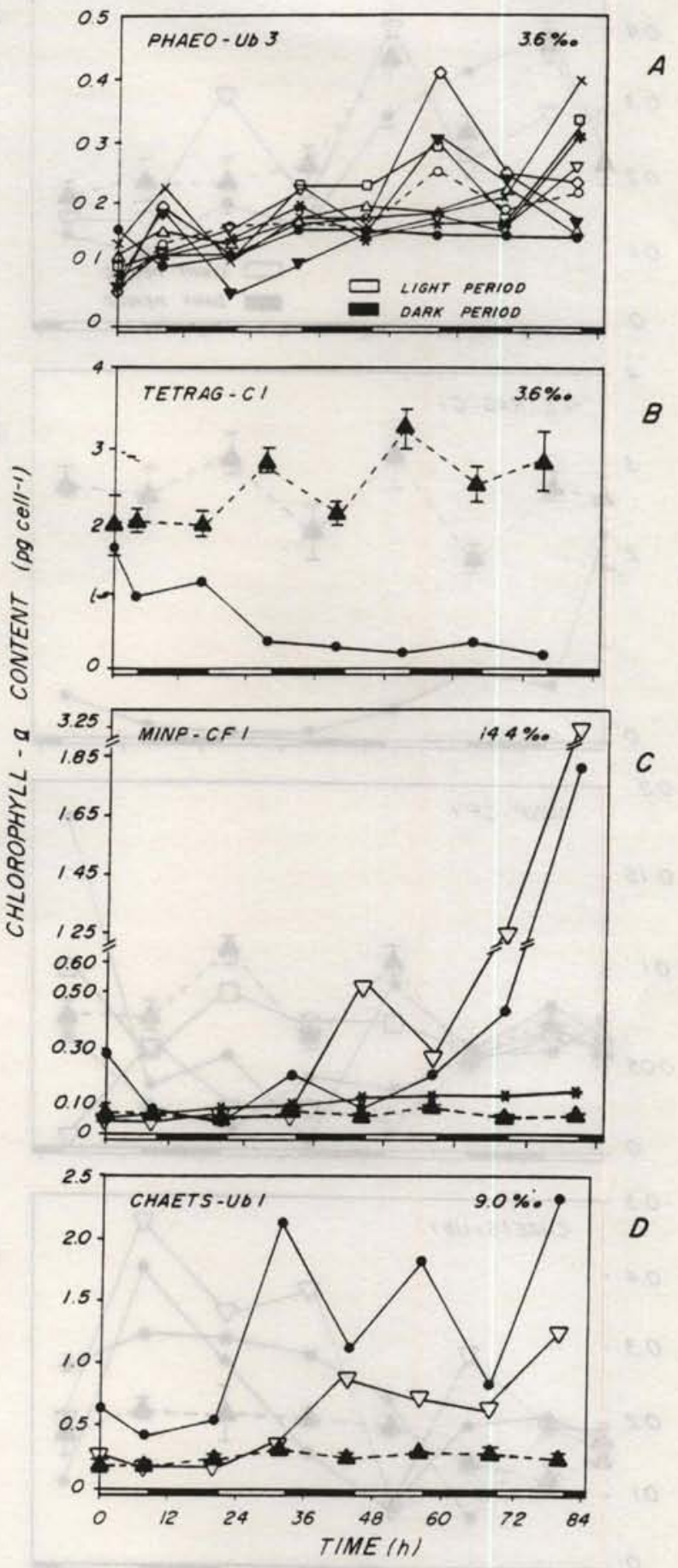

Fig. 5. Chlorophyll-a content (pg cell $\left.{ }^{-1}\right)$ as a function of time (h) for microalgae precultured at $3.6 \%$ (Phaeo-Ub3, Tetrag- C1), $14.4 \%$ 。 (Minp-CF1) or $9.0 \%$ (Chaets-Ub1), after transfer to new media of different salinities. Experimental salinities: A) • $0.3 \% \circ ; \nabla \_\nabla 3.6 \%$; * * ${ }^{*} 9.0 \%$; a_a $14.4 \%$; X_x $19.8 \%$; $\diamond \_\diamond 25.2 \%$; $\Delta \_\Delta$

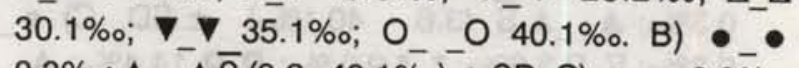
$0.3 \% \circ ; \bar{\Delta}(3.6-40.1 \% \circ) \pm$ SD. C) • $\bullet 0.3 \%$; $\nabla \_\nabla 3.6 \%$; * * $9.0 \%$; $\Delta \bar{S}(14.4-\overline{40.1} \% \circ) \pm$ SD. D) • $-\overline{0} .3 \% \circ ; \nabla \bar{\nabla} 3.6 \% \circ ; \Delta_{-} \Delta \bar{S}(9.0-$ $40.1 \% \circ) \pm$ SD. 

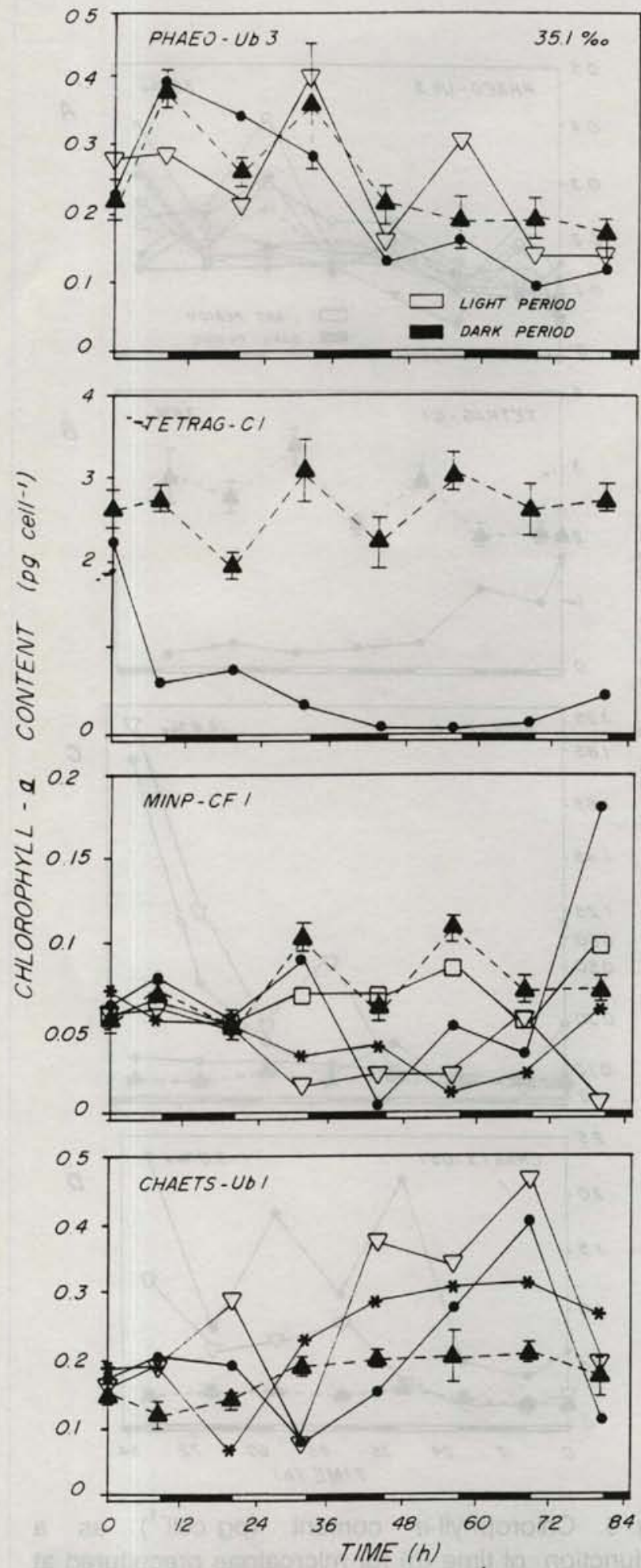

Fig. 6. Chlorophyll-a content (pg cell $\left.{ }^{-1}\right)$ as a function of time (h) for microalgae precultured at $35.1 \%$, after transfer to new media of different salinities. Experimental salinities: A) - $\bullet \quad 0.3 \%$; $\nabla$ _ $\nabla$ $3.6 \%$; $\Delta \bar{\Delta}(9.0-40.1 \% \circ) \pm$ SD. B) $0.3 \% ; \Delta_{-} \overline{\mathrm{S}}(3.6-40.1 \% \mathrm{o}) \pm \mathrm{SD}$. C)

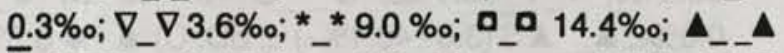
$\bar{S}(19.8-40.1 \% \circ) \pm S D$. D) $-\bullet 0.3 \% \circ ; \bar{\nabla} \nabla$ $3.6 \%$; * * $9.0 \% \circ, \Delta \_\bar{S}(14.4-40.1 \% \circ) \pm S \bar{S}$.

\section{Discussion}

The species investigated showed different degrees of physiological adjustment to new salinity media. $P$. tricornutum presented high values of maximum growth rate (Fig. 1) in almost the whole salinity range, being less dependent on previous salinity conditions. Shimura et al. (1979) obtained similar results for the estuarine clone of $P$. tricomutum studied. This clone grew between 1.0-69.2\%o and $1.0-40.0 \%$, for preconditioning salinities of $34.6 \%$ and $1.0 \%$, respectively.

Concerning maximum growth rate results (Fig. 1), Chaetoceros sp seemed to be the organism which presented the most pronounced shift in the salinity optimum as a function of preconditioning. When cells were precultured at $35.1 \%$, maximum values were found at $30.1 \%$ and $35.1 \%$. At approximately the same preconditioning salinity, for an estuarine strain referred also as Chaetoceros sp, Shimura et al. (op. cit.) obtained a broader range $(8.7-40.0 \%)$. For cells precultured at $9.0 \%$, the clone isolated from Brazilian coastal waters exhibited maximum values at $14.4 \%$ and $19.8 \%$.

T. gracilis and $M$. polymorphus could also shift adaptively their salinity optimum for maximum growth rate (Fig. 1). When placed under different salinity regimes, $T$. gracilis cells precultured at $3.6 \%$ showed almost constant growth rate values from $9.0 \%$ to $40.1 \%$. For those cells previously incubated at $35.1 \%$, the salinity optimum shifted toward the highest salinity values (19.8-40.1\%o). This optimum plasticity could be of extreme importance, from an ecological point of view, for an estuarine organism such as $T$. gracilis. Hellebust (1976) examined the physiological behaviour of Tetraselmis suecica (referred to as Platymonas suecica) in relation to salinity variations. This flagellate, precultured at $34.0 \%$, grew between 3.4-102.0\%o. This organism was able to maintain almost constant growth rates $\left(1.2 \mathrm{div} \mathrm{d}^{-1}\right)$ from $6.8 \%$ o to $68.0 \%$. $M$. polymorphus revealed optimum salinity range between 14.4-30.1\%o for cells precultured at $14.4 \%$. When cells were previously incubated at $35.1 \%$, their salinity optimum extended to $40.1 \%$.

The most sensitive growth parameter to the preconditioning effect was lag time (Fig. 2): For all treatments, even for the control salinities, a lag phase of growth was observed when cells were transferred from parent cultures into different salinity media. It might be at least in part due to the age of cells used as inocula which came from stationary or late exponential growth phase. In fact, this was verified in the growth curves of each species, adapted to each salinity, under the optimum temperature conditions (Sigaud, 1990). 
Shimura et al. (1979) had shown that the length of the lag phase was closely related to the salinity of the new media. It prolonged progressively in media with salinities lower or higher than that of parent cultures. Hellebust (op. cit.) observed a similar tendency for $T$. suecica precultured at $34.0 \%$. When cells were incubated in media of $17.0 \%$ and $51.0 \%$ salinities, the lag time was shorter than 1 day. Time induction increased up to 2-3 days, when cells were submitted to salinities about $3.4 \%$, $6.8 \%$ and $68.0 \%$. The adaptation period was even longer (4-5 days) for cells transferred to $85.0 \% 0$ and $102.0 \%$. The four species examined presented an analagous behaviour when placed into different salinity media. Lag time was comparatively longer in low salinity extremes for cells previously incubated at $35.1 \%$. On the opposite, there was an increased induction in high salinities for those preconditioned at the lowest experimental salinities of growth.

All organisms studied showed rhythmic fluctuations of both specific growth rate (Figs 3 and 4) and chlorophyll- $a$ content (Figs 5 and 6) related lo light-dark cycles.

According to Chisholm \& Costello (1980) it is not surprising the coupling between cell cycle and light-dark cycle, since phytoplankton depends on light supply for growth. Evidence from field (Swift \& Durbin, 1972 ; Smayda, 1975; Weiler \& Chisholm, 1976) and culture (Jorgensen, 1966; Eppley et al., 1967; Paasche, 1967, 1968; Nelson \& Brand, 1979) studies showed a 24-h periodicity on the instantaneous population division rate.

Considering diatom species, the widespread understanding that they do not obey a classical pattern of cell division must be kept in mind. Traditional concepts of synchronized or phased cell division are not always aplicable to them. Besides, this group seems to be largely affected by environmental variability (Chisholm et al., 1980).

Chaetoceros sp and $M$. polymorphus divided preferentially during the light period. On the other hand, $P$. tricormutum and $T$. gracilis behaved as the majority of documented phytoplanktonic species, dividing primarily during the dark period (Nelson \& Brand, op. cit.; Chisholm \& Brand, 1981). However, Ricketts (1977) established for Tetraselmis striata (referred to as Platymonas striata) that cells divided at the onset of darkness, but remained attached until exposed to light $10 \mathrm{~h}$ later. Palmer et al. (1964) suggested a rhythm in cell division of $P$. tricornutum, with increases in cell number taking place during the second half of the dark period and the first half of the light period. Distinct strains of $P$. tricornutum, growing under cyclic light regimes, showed high cell division frequencies during the dark period (Terry et al., 1983).
For the species evaluated, chlorophyll synthesis occurred during light exposition. Thus, this process alternated with cell division in $P$. tricomutum and $T$.gracilis. In Chaetoceros sp and $M$. polymorphus both processes were related to the same period of the light-dark cycle.

For $T$. striata, pigments were synthesized during the light period. Specially for chlorophyll- $a$, maximum synthesis took place 5 to $8 \mathrm{~h}$ after the onset of the light period (Ricketts, 1977). T. gracilis seemed to behave similarly. However, there is a lack of knowledge of this subject.

Different isolates of $P$. tricornutum showed a significantly greater chlorophyll- $a$ synthesis during light exposition, although the synthesis really succeeded in both periods. The synthesis rate during the dark period was dependent on the photosynthetically active radiation level of the light period (Terry et al., op. cit.).

Skeletonema costatum presented a high cellular chlorophyll- $a$ content only during the light period (Jorgensen, 1966). In this species, chlorophyll-a concentration increased during the development of cells and decreased automatically during cell division. The lowest concentrations were found in the middle of the dark period, in young cells. Chaetoceros sp and $M$. polymorphus could present a similar behaviour. However, a greater number of observations, during a 24 -h period, should be necessary to elucidate this question.

The cyclic pattern exhibited by the cellular chlorophyll- $a$ content was altered under stressed salinity conditions, when cellular division rate was inhibited. This behaviour could be mainly noticed in the case of cells transferred into low salinity media. A similar trend was demonstrated for Platymonas $\mathrm{sp}$, which showed maximum chlorophyll concentrations at the extremes of the salinity range (McLachlan, 1961). According to this author, low salinities might restrict cell division, without affecting chlorophyll synthesis to the same extent.

Based on the present data, it may be concluded that the studied species were able to displace their salinity optimum for growth at different degrees. $P$. tricomutum seemed to be quite indifferent to preconditioning salinity, showing the greatest capability of physiological adjustment to new salinity conditions. This metabolic plasticity was progressively reduced for $T$. gracilis and $M$. polymorphus. Chaetoceros sp exhibited the narrowest salinity optima as a result of preculturing salinity, demonstrating the highest sensitivity to osmotic stresses.

The response patterns presented here may allow us to infer about the potential of metabolic adjustment of phytoplankton to salinity regimes in environmental conditions, although in nature such a wide salinity variation is less probable to occur. 


\section{Conclusions}

1 - The four species studied were able to shift their salinity optimum for growth according to preculturing salinity conditions. $P$. tricomutum showed the greatest capability of physiological adjustment to external salinity changes, whereas Chaetoceros sp was the most sensitive species to osmotic stresses.

2 - All tested species exhibited fluctuations of the specific growth rate related to light-dark cycles. In $P$. tricomutum and $T$. gracilis cell division takes place during the dark period, whereas $M$. polymorphus and Chaetoceros sp divide preferentially in the light period.

3 - Chlorophyll- $a$ content showed cyclic variations, related to light-dark cycles. In all species, chlorophyll- $a$ synthesis succeeds in the light period.

4 - The physiological responses of the tested species to osmotic shocks presented here evidenced the potential of metabolic adjustment of phytoplankton to external salinity changes. The response pattern varies according to the organism and probably depends on its environmental history.

\section{Acknowledgments}

This work is part of the studies developed by T. C. S. Sigaud, submitted in partial fulfillment to the requirements for the M. Sc. degree at the University of Sāo Paulo. It was conducted with financial support from CIRM - "Comissão Interministerial para os Recursos do Mar" and with an aid of a postgraduate fellowship (T.C.S.S.) provided by FAPESP - "Fundação de Amparo à Pesquisa do Estado de São Paulo". We wish to thank C. B. de Souza, S. M. Koyama and M. Fujimura for their assistance in statistical analysis.

\section{References}

BRAND, L. E., 1984. The salinity tolerance of forty-six marine phytoplankton isolates. Estuar. coast. Shelf Sci., 18:543-556.

BROWN, L. M., 1982a. Photosynthetic and growth responses to salinity in a marine isolate of Nannochoris bacillaris (Chlorophyceae). J. Phycol., 18:483-488.

BROWN, L. M., 1982b. Production of axenic cultures of algae by an osmotic method. Phycologia, 21(3):408-410.
CHISHOLM, S. W. \& BRAND, L. E. 1981. Persistence of cell division phasing in marine phytoplankton in continuous light after entraiment to light: dark cycles. J. expl mar. Biol. Ecol., 51:107-118.

CHISHOLM, S. W. \& COSTELlO, J. C. 1980. Influence of environmental factors and population composition on the timing of cell division in Thalassiosira fluviatilis (Bacillariophyceae) grown on light/dark cycles. J. Phycol., 16:375-383.

, MOREL, F. M. M. \& SLOCUM, W.S. 1980. The phasing and distribution of cell division cycles in marine diatoms. In: Falkowski, P. ed. Primary productivity in the sea. Brookhaven Symp. Biol., New York, Plenum Press, 31:281-300.

EPPLEY, R. W.; HOLMES, R. W. \& PAASCHE, E. 1967. Periodicity in cell division and physiological behavior of Ditylum brightwellii, a marine planktonic diatom, during growth in light-dark cycles. Arch. Mikrobiol., 56:305-323.

FABREGAS, J.; ABALDE, J.; HERRERO, C.; CABEZAS, B. \& VEIGA, M. 1984. Growth of the marine microalga Tetraselmis suecica in batch cultures with different salinities and nutrient concentrations. Aquaculture, 42:207-215.

; HERRERO, C.; ABALDE, J. \&

CABEZAS, B. 1985. Growth, chlorophyll $a$ and protein of the marine microalga Isochrysis galbana in batch cultures with different salinities and high nutrient concentrations. Aquaculture, 50:1-11.

ABALDE, J. 1987. Growth and biochemical variability of the marine microalga Chlorella stigmatophora in batch cultures with different salinities and nutrient gradient concentration. Br. phycol. J., 22:269-276.

GESSNER, F. \& SCHRAMM, W. 1971. Salinity: plants. In: Kinne, O. ed. Marine Ecology. Wiley-Interscience, London, v. 1, part 2, p.705820.

GUILLARD, R. R. L. 1973. Division rates. In: Stein J. R. ed. Handbook of phycological methods, culture methods and growth measurements. Cambridge Univ. Press, London. p.289- 311. 
HELLEBUST, J. A., 1976. Effect of salinity on photosynthesis and mannitol synthesis in the green flagellate Platymonas suecica. Can. J. Bot., 54:1735-1741.

JORGENSEN, E. G. 1966. Photosynthetic activity during the life cycle of synchronous Skeletonema cells. Physiol. Plant., 19:789- 799.

LIU, M. S. \& HELLEBUST, J. A. 1976. Effects of salinity changes on growth and metabolism of the marine centric diatom Cyclotella cryptica. Can. J. Bot., 54:930-937.

MAEDA, O.; ZAMMA, M. \& ICHIMURA, S. 1973. Photosynthetic response of estuarine phytoplankton to salinity variations in their habitat. La mer, 11(3):137-140.

MAHONEY, J. B. \& McLAUGHLIN, J. J. A. 1979. Salinity influence on the ecology of phytoflagellate blooms in Lower New York Bay and adjacent waters. J. expl mar. Biol. Ecol., 37(3):213-223.

McLACHLAN, J. 1961. The effect of salinity on growth and chlorophyll content in representative classes of unicellular marine algae. Can. J. Microbiol., 7:399-406.

NELSON, D. M. \& BRAND, L. E. 1979. Cell division periodicity in 13 species of marine phytoplankton on a light:dark cycle. J. Phycol., 15(1):65-75.

NETER, J., WASSERMAN, W. \& KUTNER, M. H. 1985. Applied linear statistical models Regression, analysis of variance and experimental designs $2^{\text {nd }}$ ed. R. D. Irwin, Inc., Illinois, $1127 \mathrm{p}$.

PAASCHE, E. 1967. Marine plankton algae grown with light-dark cycles. I. Coccolithus huxleyi. Physiol. Plant., 20(4):946-956.

1968. Marine plankton algae grown with light-dark cycles. II. Ditylum brightwellii and Nitzschia turgidula. Physiol. Plant., 21:66-77.

1975. The influence of salinity on the growth of some plankton diatoms from brackish water. Norw. J. Bot., 22:209-215.

PALMER, J. D.; LIVINGSTON, L. \& ZUSY, D. 1964. A persistent diurnal rhythm in photosynthetic capacity. Nature, 203:1087-1088.
PROVASOLI, L.; MCLAUGHLIN, J. J. A. \& DROOP, M.R. 1957. The development of artificial media for marine algae. Arch. Mikrobiol., 25:392-428.

QASIM, S. Z.; BHATTATHIRI, P. M. A. \& DEVASSY, V. P. 1972. The influence of salinity on the rate of photosynthesis and abundance of some tropical phytoplankton. Mar. Biol., 12(3):200-206.

RICKETTS, T. R. 1977. Changes in average cell concentrations of various constituents during synchronous division of Platymonas striata Butcher (Prasinophyceae). J. expl Bot., 28(107):1278-1288.

SHIMURA, S.; SHIBUYA, H. \& ICHIMURA, S. 1979. Growth and photosynthesis properties of some planktonic marine diatoms at various salinity regimes. La mer, 17:149-155.

SIGAUD, T. C. S. 1990. Efeitos de temperatura e salinidade sobre as respostas de crescimento e o conteúdo de clorofila- $a$ de algumas espécies de algas planctônicas, em cultura. Dissertação de mestrado. Universidade de São Paulo, Instituto Oceanográfico. 352 p.

SMAYDA, T. J. 1975. Phased cell division in natural populations of the marine diatom Ditylum brightwellii and the potential significance of diel phytoplankton behavior in the sea. Deep-Sea Res., 22:151-165.

SMAYDA, T.J. 1980. Phytoplankton species sucession. In: Morris, I. ed. The physiological ecology of phytoplankton. Blackwell Scientific Publications, Oxford, p.493-570.

STRICKLAND, J. D. H. \& PARSONS, T. R. 1968. A practical handbook of seawater analysis. Bull. Fish. Res. Bd Can., 167:311 p.

SWIFT, E. \& DURBIN, E. G. 1972. The phased division - and cytological characteristics of Pyrocystis spp can be used to estimate doubling times of their populations in the sea. Deep-Sea Res., 19:189-198.

TERRY, K. L., HIRATA, J. \& LAWS, E. A. 1983. Light-limited growth of two strains of the marine diatom Phaeodactylum tricornutum Bohlin: chemical composition, carbon partitioning and the diel periodicity of physiological processes. J. expl mar. Biol. Ecol., 68:209-227. 
TSURUTA, A.; OHGAI, M.; UENO, S. \& YAMADA, M. 1985. The effect of the chlorinity on the growth of planktonic diatom Skeletonema costatum (Greville) Cleve in vitro. Bull. japan. Soc. scient. Fish., 51(11):1883-1886.

WEILER, C. S. \& CHISHOLM, S. W. 1976. Phased cell division in natural populations of marine dinoflagellates from shipboard cultures. J. expl mar. Biol. Ecol., 25:239-247.

(Manuscript received 07 February 1994; revised 07 December 1994; accepted 03 October 1995) 